\title{
MENINGKATKAN HASIL BELAJAR SISWA DENGAN \\ MENGGUNAKAN MODEL REALISTIC MATHEMATICS \\ EDUCATION (RME) PADA MATA PELAJARAN \\ MATEMATIKA DI KELAS V SDS SALSA \\ CINTA RAKYAT
}

\author{
Daitin Tarigan $^{1}$, Irsan Rangkuti ${ }^{2}$, Arifin Siregar ${ }^{3}$ \\ Surel: daitin.tarigan@gmail.com
}

\begin{abstract}
The main problem in this study is the low learning outcomes of fifth grade students of Salsa Cinta Rakyat Elementary Elementary School Percut Sei Tuan in fractions material mathematics lessons. This research aims to improve student learning outcomes by using the Realistic Mathematics Education (RME) model on mathematics subjects in the VB class of Salsa Cinta Rakyat Private Elementary School Academic Year 2017/2018. The results of the study can be concluded that the use of the Realistic Mathematics Education (RME) learning model can improve student learning outcomes in mathematics lessons in the fifth grade fractions of Salsa Private Elementary School Love People Percut Sei Tuan
\end{abstract}

Keywords: Learning Outcomes, Models

\begin{abstract}
ABSTRAK
Permasalahan utama dalam penelitian ini adalah rendahnya hasil belajar siswa kelas V SD Swasta Salsa Cinta Rakyat Percut Sei Tuan pada pelajaran matematika materi pecahan. Penelitian yang dilakukan ini bertujuan untuk meningkatkan hasil belajar siswa dengan menggunakan model Realistic Mathematics Education (RME) pada mata pelajaran pelajaran matematika di kelas VB SD Swasta Salsa Cinta Rakyat Tahun Ajaran 2017/2018. Hasil penelitian dapat disimpulkan bahwa penggunaan model pembelajaran Realistic Mathematics Education (RME) dapat meningkatkan hasil belajar siswa pada pelajaran matematika materi pecahan kelas V SD Swasta Salsa Cinta Rakyat Percut Sei Tuan
\end{abstract}

Kata kunci: Hasil Belajar, Model

\section{PENDAHULUAN}

Melihat kenyataan tersebut, peneliti menyimpulkan bahwa dalam pembelajaran matematika perlu adanya inovasi baru dalam penyampaian materi untuk mengiringi perubahan pembelajaran yang berpusat pada guru beralih berpusat pada siswa maka sangatlah penting bagi para pendidik terutama guru untuk memahami materi, peserta didik, dan metodologi pembelajaran dalam proses pembelajaran terutama terkait dalam pemilihan model-model pembelajaran yang modern yaitu diterapkannya model-model pembelajaran inovatif, kreatif, dan

${ }^{123}$ Universitas Negeri Medan

Accepted: 3 Desember 2018 Published: 18 Desember 2018 
konstruktif untuk mengembangkan dan menggali peserta didik secara kongkrit dan mandiri dibidang pengetahuan salah satunya adalah model Realistic Mathematics Education (RME).

Model pembelajaran Realistic

Mathematics Education (RME)
diketahui sebagai model pembelajaran yang telah berhasil di Nederlands. Dalam pembelajaran matematika selama ini, dunia nyata hanya dijadikan tempat mengaplikasikan konsep. Peserta didik mengalami kesulitan matematika di kelas. Akibatnya, peserta didik kurang menghayati atau memahami konsep-konsep matematika, dan peserta didik mengalami kesulitan untuk mengaplikasikan matematika dalam kehidupan sehari-hari. Model pembelajaran Realistic Mathematics Education (RME) ini juga pernah dilakukan oleh Viccy Melinda Nurita pada kelas IV di SDN 163089 Tebing Tinggi, hasil penelitian tersebut menunjukkan bahwa terjadi peningkatan hasil belajar siswa pada mata pelajaran matematika.

\section{Realistic Mathematics}

Education (RME) adalah model pembelajaran matematika yang dikaitkan dengan kenyataan yang dekat dengan pengalaman anak dan relevan terhadap masyarakat, dengan tujuan menjadi bagian dari nilai kemanusiaan. Dalam model pembelajaran Realistic Mathematics Education (RME) atau pembelajaran matematika realistik siswa didorong atau ditantang untuk aktif dalam belajar, bahkan diharapkan dapat mengkonstruksi sendiri pengetahuan yang diperoleh.

$\begin{array}{lrr}\text { Hasil belajar merupakan } & \text { dalam }\end{array}$
pembelajaran. Menurut Purwanto (2010:45) "Hasil belajar adalah perubahan yang mengakibatkan manusia berubah dalam sikap dan tingkah lakunya". Aspek perubahan itu mengacu kepada taksonomi tujuan pengajaran yang dikembangkan oleh Bloom yaitu mencakup aspek kognitif, afektif, dan psikomotorik. Ranah kognitif berkenaan dengan hasil belajar intelektual yang terdiri dari enam aspek, yaitu: 1) Mengingat (C1); 2) Memahami

Mengaplikasikan atau Menerapkan (C3); 4) Menganalisis (C4); 5) Mengevaluasi (C5) ; 6) Menghasilkan karya atau mencipta (C6).

Model pembelajaran adalah suatu perencanaan atau suatu pola yang digunakan sebagai pedoman dalam merencanakan pembelajaran di kelas. Model tersebut merupakan pola umum perilaku pembelajaran untuk mencapai kompetensi/tujuan pembelajaran yang diharapkan. Model pembelajaran adalah pola interaksi siswa dengan guru di dalam kelas yang menyangkut model, strategi, metode, dan teknik pembelajaran yang diterapkan dalam pelaksanaan kegiatan belajar 
mengajar. Dalam suatu model pembelajaran ditentukan bukan hanya apa yang harus dilakukan guru, akan tetapi menyangkut tahapan-tahapan, prinsip-prinsip reaksi guru dan siswa serta sistem penunjang yang disyaratkan.

\section{Realistic Mathematics}

Education (RME) di Indonesia disebut juga sebagai Pendidikan Matematika Realistik (PMR). Dalam Muhsetyo (2008:116) Freudenthal dan Treffers adalah tokoh-tokoh yang mengembangkan RME, pada awalnya diterapkan di Belanda dan digunakan sebagai model untuk meningkatkan mutu pembelajaran matematika.

\section{Berdasarkan KTSP tahun} 2006 yang dirancang oleh Depdiknas, materi Matematika yang diajarkan di kelas V pada semester I meliputi operasi hitung bilangan

Bagaimana tepat dan baiknya bahan ajaran matematika yang ditetapkan belum menjamin akan tercapai tujuan pendidikan matematika yang diinginkan. Berbagai kesulitan yang dialami siswa dalam pembelajaran, yang salah satunya adalah kesulitan dalam menyelesaikan soal-soal latihan menjadi kendala dalam bulat, KPK dan FPB, akar dan perpangkatan, pengukuran, jarak dan kecepatan, dan geometri. Sedangkan materi Matematika yang diajarkan pada semester II meliputi operasi hitung bilangan pecahan.

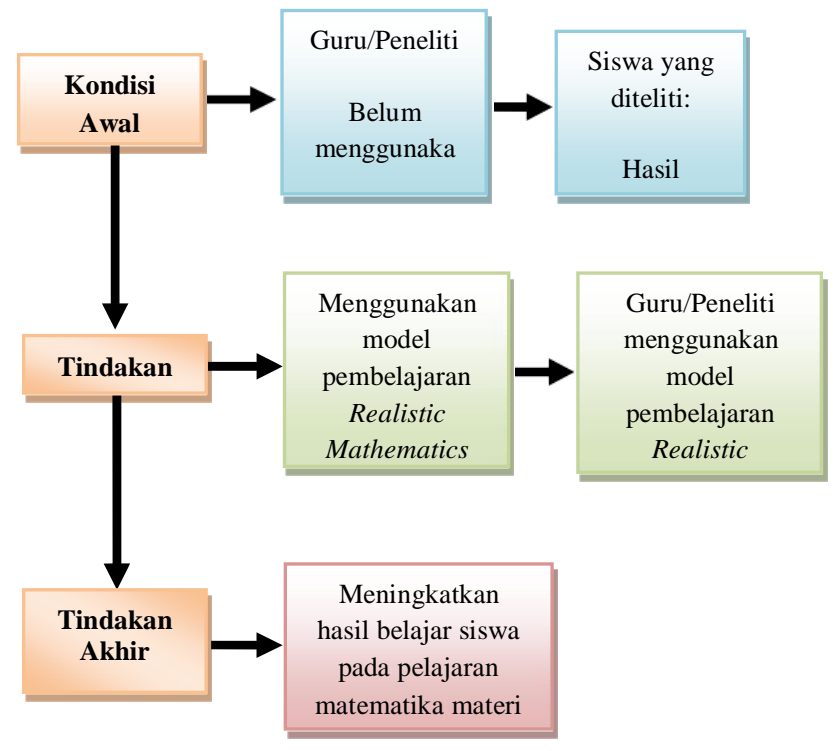

Skema Kerangka Berpikir

proses belajar mengajar yang dilaksanakan. Dalam proses belajar mengajar matematika perlu lebih menekankan keterlibatan secara optimal para peserta didik secara sadar. Salah satunya yaitu dengan menerapkan model pembelajaran Realistic Mathematics Education (RME).

\section{METODE PENELITIAN}


Penelitian ini menggunakan jenis metode Penelitian Tindakan Kelas (PTK) atau dikenal dengan Classroom Action Research, disingkat (CAR). Penelitian Tindakan Kelas (PTK) adalah penelitian tindakan yang dilakukan oleh guru dengan tujuan memperbaiki mutu praktik pembelajaran dikelasnya. Menurut Supardi (2017:194) Penelitian Tindakan Kelas (PTK) merupakan suatu penelitian yang akar permasalahannya muncul di kelas, dan dirasakan langsung oleh guru yang bersangkutan sehingga sulit dibenarkan jika ada anggapan bahwa permasalahan dalam PTK diperoleh dari persepsi/renungan seorang peneliti. Penelitian tindakan sebagai suatu bentuk investigasi yang bersifat reflektif pertisipatif, kolaboratif dan spiral, yang memiliki untuk penerapan tindakan (observation and evaluation), dan melakukan refleksi (reflecting), dan seterusnya sampai dengan perbaikan atau peningkatan yang diharapkan tercapai (kriteria keberhasilan).

Penelitian ini dilaksanakan dikelas VB SDS SALSA Kecamatan Percut Sei Tuan Tahun Ajaran 2017/2018 pada semester Genap. Waktu penelitian dilaksanakan dalam 2 bulan dari siklus I sampai siklus II mulai dari bulan April 2018.

Subjek penelitian dalam Penelitian Tindakan Kelas (PTK) ini adalah siswa kelas VB SDS SALSA
Percut Sei Tuan Tahun Ajaran 2017/2018 yang berjumlah 28 siswa. Objek penelitian ini adalah penerapan model pembelajaran Realistic Mathematics Education (RME).

Desain penelitian yang direncanakan menggunakan model Kemmis dan Mc Taggart, dimana setiap siklus terdiri dari empat tahapan yaitu, 1) perencanaan, 2) pelaksanaan, 3) pengamatan dan 4) refleksi. Adapun desain penelitiannya adalah sebagai berikut: 


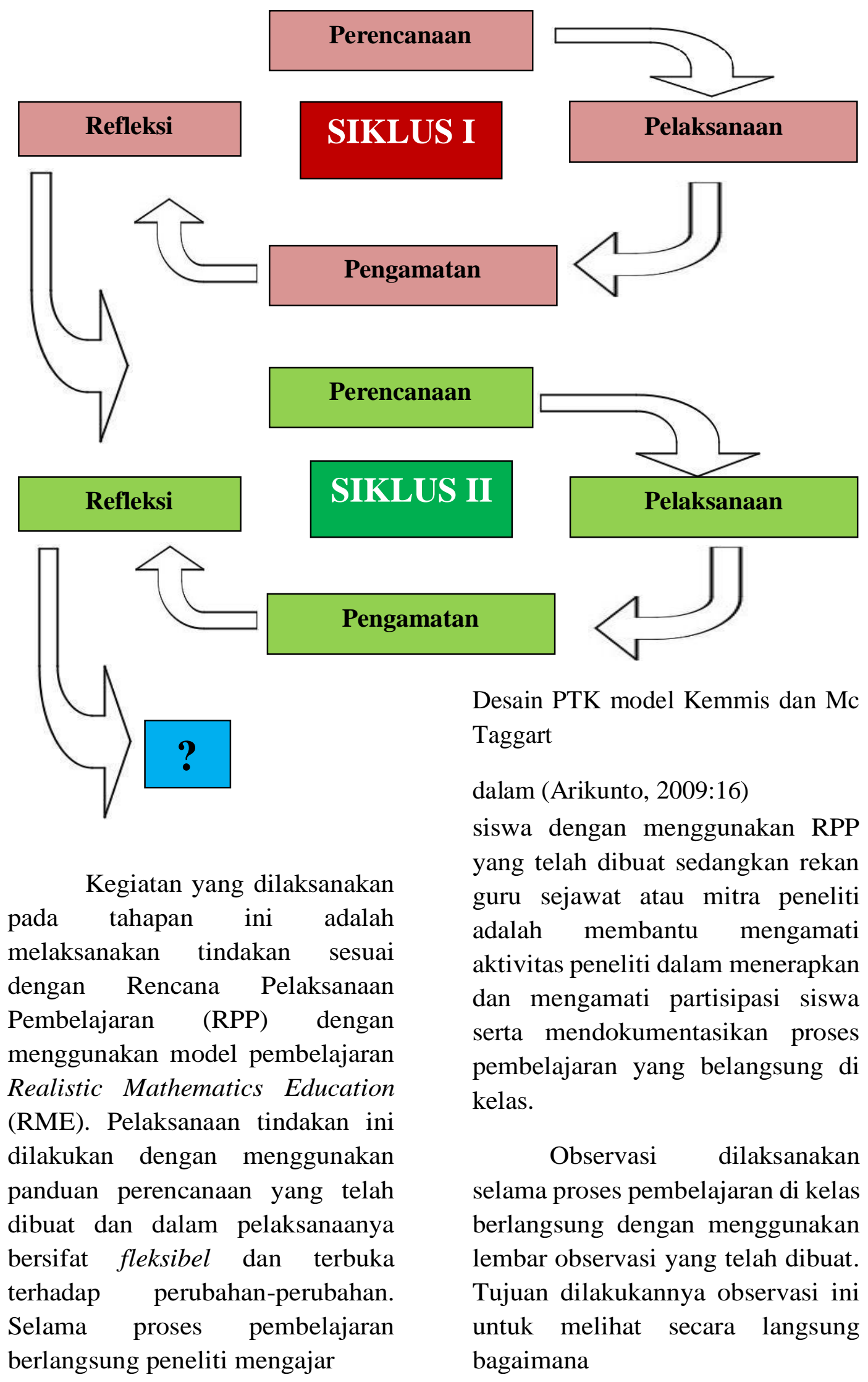


penerapan model pembelajaran yang diterapkan guru dan aktivitas siswa saat proses pembelajaran.

Teknis analisis data digunakan untuk menguji hipotesis tindakan yang telah dirumuskan. Data yang sudah terkumpul oleh peneliti lalu dianalisis untuk memperoleh hasil dari penelitian tindakan kelas yang dilaksanakan. Teknis analisis data yang digunakan dalam penelitian ini yaitu analisis data hasil belajar siswa.

Teknis analisis data hasil belajar siswa digunakan untuk menganalisis data hasil tes formatif yang dilaksanakan pada siklus I dan siklus II. Suatu kelas dikatakan tuntas belajar jika kelas tersebut terdapat $75 \%$ siswa yang telah mencapai nilai $\geq 70$. Jika hasil tes siswa mengalami kenaikan sesuai standar nilai yang telah ditentukan, maka diasumsikan dengan menerapkan model pembelajaran Realistic Mathematics Education (RME) dapat meningkatkan hasil belajar siswa. Penelitian ini direncanakan di kelas VB SDS Salsa Percut Sei Tuan dan selama 3 bulan mulai Maret-Mei.

\section{HASIL DAN PEMBAHASAN}

Penelitian ini dilaksanakan di SDS Salsa Cinta Rakyat Percut Sei Tuan di kelas VB dengan jumlah siswa Kelas VB adalah sebanyak 28 orang siswa. jumlah siswa laki-laki sebanyak 16 orang dan jumlah siswi perempuan sebanyak 12 orang. Penelitian ini dilaksanakan sesuai dengan jadwal pelajaran matematika kelas V.

Peneliti menyiapkan tiga lembar observasi. Pertama, lembar observasi guru dalam mengajar yang bertujuan untuk menilai guru dalam melaksanakan pembelajaran. Kedua, lembar observasi aktivitas belajar siswa yang bertujuan untuk mengamati aktivitas siswa dalam mengikuti proses belajar berlangsung dan ketiga, lembar observasi hasil belajar siswa yang bertujuan untuk mengetahui keberhasilan siswa dalam proses pembelajaran berdasarkan skor yang diperoleh oleh siswa. Penelitian tindakan kelas dilakukan untuk menerapkan model Realistic Mathematics Education (RME) Untuk Meningkatkan Hasil Belajar Siswa Pada Mata Pelajaran Matematika di Kelas V SDS Swasta Salsa Cinta Rakyat Percut Sei Tuan.

$$
\text { Peneliti melaksanakan }
$$
penelitian dimulai dari pemberian Pre-Test kepada seluruh siswa dengan memberikan 20 soal pilihan ganda. Tes awal (pre test) yang diberikan kepada siswa sebelum melaksanakan perencanaan tindakan bertujuan untuk mengetahui kemampuan awal siswa dan juga untuk mengetahui gambarangambaran kesulitan yang dialami oleh siswa dalam menyelesaikan soal pada pokok bahasan " operasi bilangan penjumlahan dan pengurangan pecahan" dengan 
kriteria penilaian yaitu skor yang diperoleh dibagi dengan skor maksimum kali 100 persen. Jawaban benar bernilai skor 1 dan jika salah bernilai skor 0 .

Penelitian ini dilaksanakan di SDS Salsa Cinta Rakyat Percut Sei Tuan di kelas VB dengan jumlah siswa Kelas VB adalah sebanyak 28 orang siswa. jumlah siswa laki-laki sebanyak 16 orang dan jumlah siswi perempuan sebanyak 12 orang.

Berdasarkan hasil penelitian
yang telah dilakukan, terjadi
meningkatnya hasil belajar pada
siswa kelas VB SDS Salsa Cinta
Rakyat Percut Sei Tuan setelah
dilakukan penerapan model RME
dalam pembelajaran seperti halnya
dengan memanfaatkan kue bolu dan
buah-buahan buatan yang dibawa
guru. Peningkatan tidak hanya terjadi
pada hasil belajarnya saja, tetapi juga
pada proses pembelajarannya.

Model pembelajaran Realistic Mathematics Education (RME) ini juga pernah dilakukan oleh Viccy Melinda Nurita pada kelas IV di SDN 163089 Tebing Tinggi, hasil penelitian tersebut menunjukkan bahwa terjadi peningkatan hasil belajar siswa pada mata pelajaran matematika. Dalam penelitian tersebut 20 siswa dalam kategori tuntas dan 3 siswa dalam kategori tidak tuntas sebanyak 23 siswa. terjadi peningkatan $85 \%$ dari $75 \%$ yang diharapkan.
Data dalam penelitian ini diperoleh peneliti melalui beberapa metode, yaitu metode observasi, dan metode tes. Metode observasi digunakan peneliti untuk mengetahui sejauh mana dukungan model Realistic Mathematics Education (RME) dalam pembelajaran matematika, sedangkan metode tes digunakan peneliti untuk mengetahui hasil belajar siswa pada materi pecahan di kelas VB SDS Salsa Cinta Rakyat. Peneliti menyiapkan tiga lembar observasi. Pertama, lembar observasi guru dalam mengajar yang bertujuan untuk menilai guru dalam melaksanakan pembelajaran. Kedua, lembar observasi aktivitas belajar siswa yang bertujuan untuk mengamati aktivitas siswa dalam mengikuti proses belajar berlangsung dan ketiga, lembar observasi hasil belajar siswa yang bertujuan untuk mengetahui keberhasilan siswa dalam proses pembelajaran berdasarkan skor yang diperoleh oleh siswa.

Pada pelaksanaan penelitian proses pembelajaran yang berlangsung pada siklus I dan siklus II menunjukkan bahwa meningkatnya hasil belajar siswa pada setiap siklus. Hal ini dikarenakan siswa sudah terlibat langsung dalam pembelajaran. Berdasarkan uraian di atas pada setiap siklus menunjukkan bahwa pembelajaran RME telah berhasil meningkatkan hasil belajar siswa. perbandingan hasil belajar pra siklus, 
siklus I dan siklus II dapat dililihat

Perbandingan Hasil Belajar Siswa

Pre-tes, Siklus I dan Siklus II

\begin{tabular}{|l|l|l|l|l|}
\hline No & Jenis Test & $\begin{array}{l}\text { Jumlah } \\
\text { Siswa }\end{array}$ & \multicolumn{2}{|c|}{ Jumlah Siswa } \\
\hline 1 & Pre - Tes & 28 & 1 & $\begin{array}{l}\text { Tuntas } \\
\text { Tu }\end{array}$ \\
\hline 2 & $\begin{array}{l}\text { Post - Tes } \\
\text { SIklus I }\end{array}$ & 28 & 11 & 17 \\
\hline 3 & $\begin{array}{l}\text { Post - Tes } \\
\text { SIklus II }\end{array}$ & 28 & 26 & 2 \\
\hline
\end{tabular}

pada tabel 4.3 dan diagram 4.4

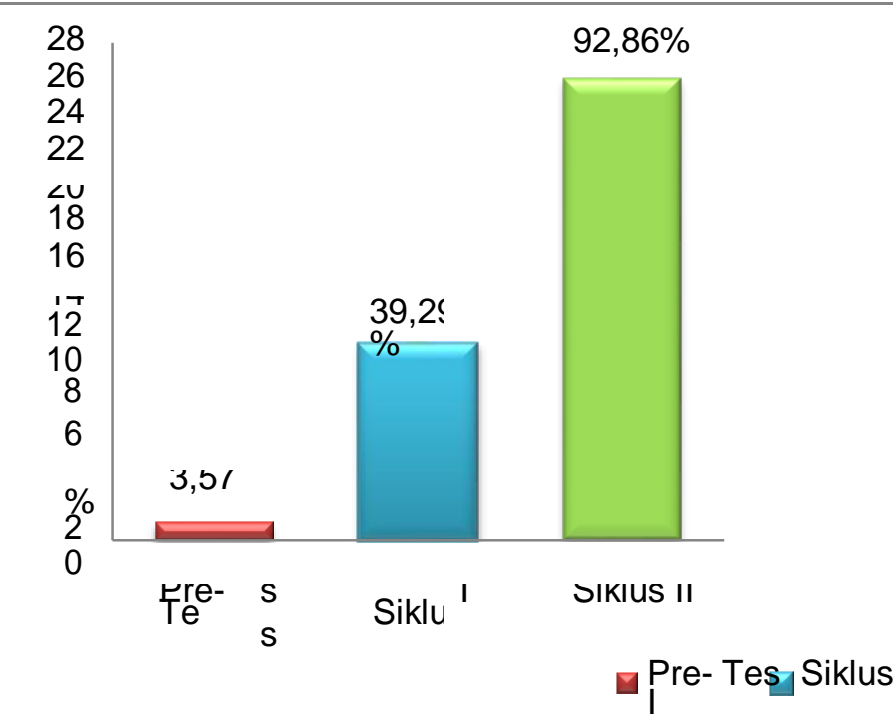

Berdasarkan pada tabel di atas pada awal sebelum dilakukan tindakan, nilai rata-rata siswa hanya mencapai 52,32 dan hanya 1 siswa atau sebesar $3,57 \%$ siswa yang mencapai KKM. Setelah dilakukan tindakan pertama dan kedua pada siklus 1 didapatkan peningkatan hasil yang cukup signifikan yaitu nilai ratarata siswa mencapai 61,79 dan sebanyak 11 siswa atau sebesar 39,29\% siswa yang mencapai KKM. Penelitian berlanjut pada siklus II, dimana setelah dilakukan tindakan pertama dan kedua terjadi peningkatan yaitu nilai rata-rata 83,93 dan sebanyak 26 siswa atau sebesar 92,86\% siswa mencapai KKM. Dari uraian tersebut menunjukkan bahwa hasil belajar siswa kelas VB SDS Salsa Cinta Rakyat mengalami peningkatan
Hasil Belajar Siswa Pre-tes, Siklus I dan Siklus II

setelah dilakukan pembelajaran matematika dengan menerapkan model Realistic Mathematics Education (RME) pada materi pecahan pokok bahasan penjumlahan dan pengurangan pecahan T.A 2017/2018.

\section{SIMPULAN}

Berdasarkan penelitian yang disajikan pada BAB IV maka dapat diambil kesimpulan yaitu Hasil belajar siswa mengalami peningkatan setelah diberikan pembelajaran dengan menggunakan model Realistic Mathematics Education (RME). Secara garis besar model Realistic Mathematics Education (RME) dapat meningkatkan hasil belajar siswa, hal itu tampak dari rata-rata hasil belajar siswa pada kondisi awal terlihat meningkat dari 
p-ISSN 2407-4934

e-ISSN 2355-1747 
61,79 Menjadi 83,93 pada kondisi akhir.

Saran

Berdasarkan hasil penelitian dan pembahasan maka peneliti memberikan saran yaitu disarankan kepada guru untuk menggunakan model Realistic Mathematics Education (RME) pada mata pelajaran matematika untuk meningkatkan hasil belajar siswa, disarankan kepada kepala sekolah untuk mengembangkan atau melatih para guru untuk terampil menggunakan berbagai model, strategi maupun model pembelajaran khususnya model Realistic Mathematics Education (RME). Sehubungan dengan meningkatnya hasil belajar siswa maka model Realistic Mathematics Education (RME) sangat tepat digunakan pada mata pelajaran matematika khususnya dalam pokok bahasan operasi bilangan pecahan.

\section{DAFTAR RUJUKAN}

Aisyah, Nyimas, dkk. 2007.

Pengembangan

Pembelajaran Matematika

SD. Jakarta: Dirjen Dikti Depdiknas.

Amri, Sofan. 2016. Pengembangan \& Model Pembelajaran dalam Kurikulum 2013. Jakarta: Prestasi Pustakaraya.

Andayani. 2009. Pemantapan

Kemampuan Profesional.

Jakarta: Universitas Terbuka
Arikunto. 2006. Penelitian Tindakan

Kelas. Jakarta: Bumi Aksara. . 2009. Penelitian Tindakan

Kelas. Jakarta: Bumi Aksara. . 2017. Penelitian Tindakan

Kelas. Jakarta: Bumi Aksara.

Aqib, Zainal. 2010. Penelitian Tindakan Kelas. Bandung: Yrama Widya

Daryanto. 2010. Inovasi Pembelajaran Efektif. Bandung: Yrama Widya

Dimyati \& Mudjiono. 2006. Belajar Dan Pembelajaran. Jakarta: Rineka Cipta.

Fathurrohman. 2015. Model-model Pembelajaran Inovatif. Jogjakarta. Ar-ruzz Media

Heruman. 2013. Model Pembelajaran Matematika di Sekolah Dasar. Bandung: Remaja Rosdakarya.

Melinda Viccy. 2015. Meningkatkan hasil belajar dengan penerapan model pembelajaran matematika realistik pada siswa kelas $I V$ di SDN 163089 Tebing Tinggi tahun 2014/2015. Universitas Negeri Medan.

Muhlisrarini \& Hamzah. 2014. Perencanaan Dan Strategi Pembelajaran Matematika. Jakarta: Rajagrafindo Persada 
Muhsetyo, Gatot. 2008. Pembelajaran Matematika SD. Jakarta: Universitas Terbuka.

Ningrum. 2014. Penelitian Tindakan Kelas. Yogyakarta: Ombak.

Purwanto. 2008. Evaluasi Hasil Belajar. Surakarta. Pustaka Belajar . 2011. Evaluasi Hasil Belajar. Jakarta: Rineka Cipta

Shoimin. 2016. Model pembelajaran inovatif dalam kurikulum 2013. Yogyakarta : Ar-Ruzz Media

Slameto. 2016. Belajar dan Faktorfaktor yang Mempengaruhinya. Jakarta: Rineka Cipta.

Sudjana, Nana. 2005. Penilaian Hasil Proses Belajar Mengajar.Bandung: Remaja Rosdakarya

Supardi. 2017. Penelitian Tindakan Kelas. Jakarta: Bumi Aksara.

Susanto, Ahmad. 2013. Teori Belajar dan Pembelajaran di Sekolah Dasar. Jakarta: Kencana.

Tandililing. 2010. Implementasi Realistic Mathematics Education (RME) disekolah. Pengaruh pendekatan Realistic Mathematics Education (RME) Terhadap Hasil Belajar Matematikan Pada Materi Geometri. Vol 25 nomor 3. Diambil dari: http://jurnal.untan.ac.id/index.p hp/jgmm/article/view/208/0

(23Maret 2018).

Tarigan, Daitin. 2006. Pembelajaran Matematika Realistik. Jakarta: Direktorat Jendral Pendidikan Tinggi.

Wijaya, Ariyadi. 2012. Pendidikan Matematika Realistik: Suatu Alternatif Pendekatan Pembelajaran Matematika. Yogyakarta: Graha Ilmu.

Wina Sanjaya. 2009. Penelitian Tindakan Kelas. Jakarta: Kencana. 
e-ISSN 2355-1747 